\title{
Devlet Konservatuvarı Opera Anasanat Dalı Öğrencilerinin Piyano Dersine İlişkin Tutumlarının İncelenmesi
}

\author{
Turgay Tunç*, Cemalettin Baydağ ${ }^{* *}$
}

DOI: $10.35675 /$ befdergi.734466

$\ddot{O} z$

Bu çalışmada, Devlet Konservatuvarı Opera Anasanat Dalı ögrrencilerinin piyano dersine ilişkin tutumlarının incelenmesi amaçlanmıştır. Araştırmanın çalışma grubunu, 2016-2017 eğitim ögretim yılında, Batı Karadeniz bölgesinde yer alan bir devlet üniversitesinde lisans öğrenimi gören 38 konservatuvar ögrencisi oluşturmaktadır. Araştırmanın nicel kısmında genel tarama modeli kullanilırken, nitel kısmında ise yedi ögrenciyle görüşmeler yapılmıştır. Öğrencilerin piyano dersine ilişkin tutumlarını düzeyini belirlemek için "Piyano Dersine Yönelik Tutum Ölçeği”" kullanılmıştır. Elde edilen nicel veriler, çift yönlü varyans analizi ile değerlendirilmiş, verileri çözümlemede ise "aritmetik ortalama", "yüzde" ve "frekans" dağılımları kullanılmıştır. Nitel verilerin analizinde betimsel analiz yöntemi kullanılmıştır. Araştırma sonucunda, ögrencilerin piyano dersine iliş̧kin tutumları arasında cinsiyet değişkenine göre anlamlı bir farklılık bulunmazken, piyano dersine ait not ortalamaları ile tutumlar arasında anlamlı bir farklılık olduğu görülmüştür. Öğrencilerin piyano dersine ilişskin tutumlarının ise orta düzeyde olduğu sonucuna ulaşılmıştır. Görüşmeler sonucunda; ögrencilerin genel olarak piyano dersinin gerekli olduğuna inandıklarl, piyano dersinin zorunlu olması gerektiğini düşündükleri ortaya çıkmıştır.

Anahtar Kelimeler: Opera, piyano, tutum

\section{Investigating The Attitudes of the State Conservatory Opera Department Students Towards the Piano Lesson}

\section{Abstract}

In this study, it was aimed to investigate attitudes of the State Conservatory Opera Department students towards piano lesson. The sample consisted of 38 conservatory students in 2016-2017 academic year. While the survey model was used in the quantitative part, interviews were conducted with seven students in the qualitative part. The "Attitude Scale towards the Piano Lesson" was used to determine the level of attitudes about the piano lesson. Two-way analysis of variance, "mean", "percentage" and "frequency" distributions were used to analyze quantitative data. Descriptive analysis was used to analyze qualitative data. In

\footnotetext{
* Bu çalışma, VII. Uluslararası Eğitimde Araştırmalar Kongresi'nde sunulmuştur.

** Zonguldak Bülent Ecevit Üniversitesi, Devlet Konservatuvarı, Müzik Bölümü, Piyano Anasanat Dalı, Zonguldak, Türkiye, trgtunc@ gmail.com, ORCID: 0000-0002-5257-5469

*** Zonguldak Bülent Ecevit Üniversitesi, Devlet Konservatuvarı, Sahne Sanatları Bölümü, Opera Anasanat Dal1, Zonguldak, Türkiye, cemalettinbaydag@gmail.com, ORCID: 00000001-5806-6844
}

Kaynak Gösterme: Tunç, T., \& Baydağ, C. (2021). Devlet konservatuvarı opera anasanat dalı öğrencilerinin piyano dersine ilişkin tutumlarının incelenmesi. Bayburt Eğitim Fakültesi Dergisi, 16(31), 63-79. https://doi.org/10.35675/befdergi.734466. 
conclusion, there was no significant difference in the attitudes of students with respect to gender, while there was a significant difference in the attitudes with respect to average scores of piano lessons. It was concluded that the students' attitudes towards the piano lesson were moderate and they believed that piano lesson was necessary and should be compulsory.

Keywords: Attitude, opera, piano

\section{Giriş}

Müzik, insanların duygularını seslerle ifade etmek için kullandıkları bir anlatım aracı olarak tanımlanabilir. Diğer bir ifadeyle "Müzik; duygu, düşünce, tasarım ve izlenimleri, belirli bir amaç ve yöntemle, belirli bir güzellik anlayışına göre birleştirilmiş seslerle işleyip anlatan estetik bir bütün" (Uçan, 1994, s. 10) olarak tanımlanmaktadır. Kullanılan seslerin belli bir ahenk ve uyum içindeki seyrinin, ortaya çıkan müziğin estetik bütünlüğü ve güzelliği çerçevesinde, dinleyici tarafindan hissedilen duyguların pekişmesinde etkili rol oynadığı söylenebilir. Ayrıca müzik, insan yaşamına bilişsel, duyuşsal ve devinişsel özelliklerin yanı sıra, duygusal anlamda da önemli katkıları olan bir araçtır (Göcü, 2016). Bu araç, insan davranışları üzerinde farklı etkilere yol açabilmekte ya da davranışlara yön verebilmektedir. Dolayısıyla bireyin kızgın, endişeli, mutlu ya da üzgün olması gibi birçok duygu durumu değişimi, müziğin insan hayatına etkisinin bir göstergesidir.

Genelde müzik eğitimi özelde de piyano eğitimi düşünüldüğünde, birçok faktörün eğitim sürecini olumlu ya da olumsuz şekillerde etkilediği görülmektedir. Çünkü eğitim safhasında öğretim, öğrenme ve öğretme kavramlarının birbiri ile ilişkili olduğu görülmektedir (Çelik Nayır, 2018, s. 2). Bu anlamda öğrencilerin akademik başarısını ve kariyer durumlarını etkileyen faktörlerden birisi hiç şüphesiz tutumdur. Nitekim bireylerin hem insani ilişkilerine hem de eğitim öğretim sürecine yönelik oluşan tutumları, günlük yaşantı sırasında karşılaştı̆̆ durumlar ya da çevre faktörü gibi belirtiler neticesinde şekillenmektedir.

Tutum, bireylerin psikolojik nesneye ilişkin duygu, düşünce ve davranışlarını düzenli biçimde etkileyen bir eğilimdir (Kağıtçıbaşı, 2005). Bunun yanında, bireyin çevresindeki herhangi bir olgu ya da nesneye ilişkin sahip olduğu tepki eğilimini ifade eder. (İnceoğlu, 2011). Bu eğilim, tutumların dayandıkları inanç ve değer yargıları devam ettiği sürece devamlılıklarını sürdürmektedir (Eren, 2001). Tutumlar belirli değer yargılarının ve inançların içinde gizlidir. Tutum, bireyin kendisi ile ilgili olarak belirli değer yargılarına ve inançlarına bağlı kalarak ortaya çıkan tanıma sürecidir (Çöllü \& Öztürk, 2006).

Psikolojik bir düşünsel çerçeve içerisinde ve toplumsal değer ile ilişkilerin sonucunda oluşan (Sönmezöz, 2014) tutumlar; bireyin zihninde bulunarak, birçok düşünce ve davranışa temel oluşturmakta (Gürşen Otacıoğlu, 2010), tutumlar ile öğrenci başarısı arasında önemli bir ilişki bulunmaktadır (Ekici, 2012). Bunun yanında, tutumlar verdiğimiz kararlarda, yaptığımız eylemlerde kısacası hayatımızda çok etkilidirler. Ayrıca, tutumların bireyler üzerinde oluşturduğu etki her ne kadar 
doğrudan gözlenemese bile, bireyin duygu, düşünce ve davranışlarının temelinde tutumun büyük bir etkisi olduğu düşünülmektedir. $\mathrm{Bu}$ sebeple tutum, "olumlu düşüncelere sahip olma, dersi sevme ya da dersle ilgili olarak olumlu giriş özellikleri gösterme davranışından, bir derse karşı olumsuz düşüncelere sahip olma, dersi sevmeme ya da dersle ilgili olarak olumsuz giriş özellikleri gösterme davranışına kadar uzanan bir süreci kapsamaktadır" (Bloom, 1995, s.90). Bununla birlikte tutum, müzik öğretim yaklaşımlarından etkilenme durumuna sahip olan değişkenlerden birisi olarak öne çıkmaktadır (Öztürk \& Kalyoncu, 2018). Bu düşünce doğrultusunda, günlük yaşamdan eğitim hayatına kadar hayatın hemen her alanında etkisini hissettiren tutumların, özellikle eğitim-öğretim sürecinde değerlendirilmesi ve doğru yönlendirilmesinde (Ekici, 2012) bireyin tutumlarının bilinmesi ve ölçülmesi büyük önem arz etmektedir (Baydağ, 2020).

Müziğin eğitim boyutuna gelindiğinde ise, müzik eğitimi bireylere düşünme becerisi kazandırmanın yanında, problem çözme ve bu amaca yönelik nasıl işbirlikçi çalışılması gerektiği konusunda da yardımcı olmaktadır (Şendurur \& Akgül Barış, 2002). Böylece müzik eğitimi, akademik ve kişisel becerilerin gelişimi neticesinde ileriye yönelik tutumları etkilemektedir. Söz konusu gelişimin etkili olabilmesi, bir çalgı çalabilme yetisi ile gerçekleşebilmektedir. Ancak çalgı çalabilme yetisi de tek başına yeterli değildir. İleriye yönelik tutum ve davranışlardaki değişiklik ancak bir eğitim süreci sonunda gerçekleşebilir. Çünkü insanoğlu, yaşamın ilk evresinden itibaren sahip olduğu tek çalgı olan sesini yıllar süren çaba ve emek ile geliştirmiştir. Çalgı ya da diğer bir deyişle çalgı eğitimi, müzik eğitiminin önemli basamaklarından birini oluşturmaktadır. Çalgı eğitimi belirli bir plan ve çalışma disiplini çerçevesinde, kişiye farklı müzik dönemleri, stilleri, eğitim müziği dağarcı̆̆ı ile bireyin mesleki yaşamında çizeceği yönü bulmasında yol gösterici konumda yer alabilmektedir. Bunlara bağlı olarak çalg1 eğitiminin, genel müzik eğitiminin önemli bir yapı taşı olduğunu söylemek yanlış olmayacaktır. Bu açıdan araştırma konusunu kapsayan piyano eğitimi ileri düzey beceri gerektiren bir kazanım olmasının yanı sıra, zihinsel, fiziksel ve duyuşsal süreçleri içinde barındıran karmaşık bir etkinlik olarak da görülebilmektedir (Gasımova, 2010). Dolayısıyla yukarıda değinilen söz konusu süreçler düşünüldüğünde, piyano eğitiminin mesleki müzik eğitimi içerisinde en önemli boyutlardan birini teşkil ettiği söylenebilir. Çünkü piyano eğitimi, bireye geniş bir literatür bilgisi, çoksesli düşünebilme ve çalabilme yetisi ile hem bir eğitim alanı olarak hem de etkili bir eğitimi aracı olarak çalgı eğitiminde önemli bir yere sahiptir (Yazıc1, 2013). Bu eğitimin içeriğini, teknik kazanımlar için alıştırma ve etütler, eğitim müziği örnekleri, Türk ve dünya bestecilerine ait piyano literatürü örnekleri kapsamaktadır (Tufan \& Güdek, 2008).

Kılıç’ın (2006) “AGSL Öğrencilerinin Piyano Derslerindeki Başarı Durumlarının Değerlendirilmesi” isimli çalışmasında, öğrencilerin kendi yapısından kaynaklanabilecek olan piyanoya ilgi duyma, piyano dersinde bilgilerini arttırıp yeteneklerini geliştirmeye karşı istekli olma gibi öznel koşulların durumu olumlu yönde arttıkça, öğrencinin başarısının da artabileceği sonucuna ulaşılmıştır. Çalışma 
örneklemini on iki AGSL son sınıf öğrencilerinin derslerine giren piyano öğretmenleri oluşturmaktadır.

"Müzik öğretmeni adaylarının piyanonun kullanımına ilişkin gösterecekleri beceri ve yeterlilikleri müzik eğitimi bölümüne girişteki hazır bulunuşluk düzeylerine, motivasyonlarına, piyano çalma koşullarına, piyano çalışmaya ayırdıkları zamana, öğreticilere, piyano ders tanımlarına (hedefler), piyano dersinde kullanılan materyallere, müzik alanına ilişkin dersler arasındaki dayanışıklığa ve piyanoda kazanılan becerilerin sıklıkla uygulama alanı bulmasıyla doğrudan ilişkilidir" (Özen, 1998, s. 93).

Bu görüşün konservatuvar gibi mesleki müzik eğitimi veren diğer kurumlar için de geçerli olduğu söylenebilir. Çünkü bu kurumlardan mezun olan öğrenciler içerisinde öğretmenlik mesleğini tercih edenler de mevcuttur. Konservatuvar ve Güzel Sanatlar Fakültelerinde müziğin bir dalına yönelik kazandıkları bilgi ve tecrübeleri başkalarına aktarıp aktarmayacaklarına bakılmaksızın, sahne performanslarının niteliğine odaklanan bir eğitim verilmektedir. Nitekim daha sonra ekonomik koşullar başta olmak üzere, pek çok sebep Konservatuvar ve Güzel Sanatlar Fakültesi mezunlarını öğretmenlik mesleğini tercih etmeye zorlamaktadır (Türkmen, 2018). Söz konusu durum, öğrencilerin gelecek kaygılarından dolayı öğretmenlik mesleğini hedef olarak belirlemelerinde etkili olmakta ve dolayısıyla konservatuvar öğrencilerinin piyano dersine ilişkin tutumları da bu anlamda önem kazanmaktadır. Değinilen öğretmenlik durumunun dışında başka faktörlerin de olduğu unutulmamalıdır. Piyano eğitimi, bir müzisyenin yaşamında yol gösterici konumu ile diğer çalgılardan ayrılmaktadır. Çünkü piyano, aralık ve akor bilgisi, deşifre becerisi, armoni, kulak ve solfej eğitimi (seslendirilen eserin temiz entonasyonda olmasında piyanonun referans alınması) ile ses egzersizlerinin en uygun ve verimli şekilde piyano ile yapılabilmesinin mümkün olduğu büyük bir yardımcı olarak ön plana çıkmaktadır.

Bir opera eserinin müzikal dinamiklerinin seslendirilmesi, eser içerisinde armoni ve form açısından nasıl bir yansımanın oluştuğunun duyulması (akorun aynı anda duyurulabilmesi ve seslendirilen akor içinde istenen duyguya ilişkin ipuçlarının yer alması), bazı durumlarda operada yer alan karaktere ilişkin duygulara piyano partisyonunda yer verilmesi, piyano eğitimine olan ilgiyle eş zamanlı bir durum sergilemektedir. Bunun yanında bireyin piyano eğitimi ile her dönemin farklı özellikleri ve stilleri hakkında kazanım elde etmesi, piyanoda yer alan cümleyi seslendireceği esere aktarabilmesi, yorum yeteneğini geliştirebilmesi ve sahne performansına katkı sağlaması açısından opera anasanat dalı öğrencilerinin piyano dersine ilişkin tutumlarının ne durumda olduğu önem arz etmektedir.

Yukarıda değinilen bilgilerden hareketle, Devlet Konservatuvarı Opera Anasanat Dalı öğrencilerinin piyano dersine ilişkin tutumlarının belirlenmesi, hem piyano eğitim programının öğrenci gelişimine ilişkin başarı durumu hakkında bilgi sağlaması açısından, hem de uygulanan ölçek sonucunda tutumlar üzerine yaşanan problem 
durumlarının saptanması ve çözümüne ilişkin önemli katkılar sağlaması açısından önem arz edeceği düşünülmektedir.

\section{Araştırmanın Amacı}

$\mathrm{Bu}$ araştırmada, Devlet Konservatuvarı Opera Anasanat Dalı öğrencilerinin piyano dersine ilişkin tutumlarını saptamak amaçlanmıştır. Ayrıca öğrencilerin tutumları ile cinsiyet ve piyano not ortalamaları arasında herhangi bir farklılık olup olmadığı tespit edilmeye çalışılmıştır.

\section{Problem Cümlesi ve Alt Problemler}

Araştırmanın amacı doğrultusunda, araştırmanın problem cümlesi "Devlet Konservatuvarı Opera Anasanat Dalı öğrencilerinin piyano dersine ilişkin tutumları arasında farklılık var mıdır?” olarak belirlenmiştir. Buna bağlı olarak çalışmanın alt problemleri ise aşağıdaki gibidir.

1. Devlet Konservatuvarı Opera Anasanat Dalı öğrencilerinin piyano dersine ilişkin tutumları ile cinsiyet değișkeni arasında anlamlı bir farklılık var mıdır?

2. Devlet Konservatuvarı Opera Anasanat Dalı öğrencilerinin piyano dersine ilişkin tutumları ile piyano dersi not ortalamaları arasında anlamlı bir farklılık var midir?

3. Devlet Konservatuvarı Opera Anasanat Dalı öğrencilerinin piyano dersine ilişkin tutumları nasıldır?

\section{Yöntem}

$\mathrm{Bu}$ araştırmada, karma yöntem desenlerinden "açımlayıcı sıralı desen” tercih edilmiştir. Açımlayıcı sıralı desen, araştırma sorusuna öncelikle yanıt veren nicel verilerin toplanması ve verilerin çözümlenmesiyle başlar. Daha sonra nicel araştırma bulgularına dayanarak nitel verilerin toplanması ve çözümlenmesinin ardından, nitel bulguların nicel bulguları açıklamasından yararlanılıp araştırmanın genel amacı ile bütünleştirilerek rapor edilmesiyle tamamlanır (Creswell \& Plano Clark, 2015). Benzer şekilde bu çalışmada Devlet Konservatuvarı Opera Anasanat Dalı öğrencilerinin piyano dersine ilişkin tutumlarını saptamak amacıyla nicel ve nitel araştırma yöntemleri birlikte kullanılmıştır. Öğrencilerin piyano dersine ilişkin tutumlarını derinlemesine incelemek amacıyla nicel veriler nitel verilerle desteklenmiştir. Araştırmacılar çalışmanın tüm aşamalarında araştırma ve yayın etiği kurallarının tümüne uymuştur.

\section{Çalışma Grubu}

Araştırmanın çalışma grubunu, 2016 - 2017 eğitim öğretim yılı bahar dönemimde, Batı Karadeniz bölgesinde yer alan bir üniversitenin Devlet Konservatuvarı Sahne 
Sanatları Bölümü Opera Anasanat Dalında, lisans öğrenimi gören 28’i (\%74) kadın, 10 ’u (\%26) erkek olmak üzere toplam 38 öğrenci oluşturmuştur.

\section{Veri Toplama Araçları}

Çalışmada ölçme aracı olarak Tufan ve Güdek (2008) tarafindan geliştirilen "Piyano Dersine Yönelik Tutum Ölçeği” kullanılmıştır. Ölçek, iki kısımdan oluşmakta olup, ilk kısımda demografik verilere ilişkin bilgilere, ikinci kısımda ise Piyano Dersine Yönelik Tutum Ölçeğine ait sorulara yer verilmiştir. 18 maddesi olumlu, 12 maddesi olumsuz olmak üzere toplam 30 maddeden oluşan ölçekte 5'li likert tipi soru kullanılmıştır. Ölçek maddeleri "Kuvvetle Katılırım (5)", "Katılırım (4)", "Kararsızım (3)", "Katılmam (2)" ve “Asla Katılmam (1)" biçiminde puanlanmaktadır. Bunlara ek olarak, ölçek iki alt boyuttan oluşmaktadır. "Hoşnutluk" alt boyutu 18 madde, "değer" alt boyutunda ise 12 madde yer almaktadır. Bu çalışma için ölçeğin Cronbach Alpha güvenirlik katsayısı 0.94 olarak hesaplanmıştır. Bu sonuca göre, ölçeğin öğrencilerin piyano dersine iliş̧kin tutumlarının ölçmek için güvenilir bir ölçek olduğu söylenebilir (Pallant, 2007). Ölçekte, öğrencilerin piyano dersine yönelik tutumlarını ölçmeye yönelik toplam 30 soru maddesi bulunmaktadır. Olumsuz köklü maddeler ters çevirilerek puanlanmıştır. Araştırmada, piyano not ortalamaları ve cinsiyet değişkeni gibi demografik veriler toplanmıştır. Araştırmanın nitel verilerini toplamak için rastgele seçilmiş yedi öğrenciyle yarı-yapılandırılmış görüşmeler yapılmıştır. Görüşme sırasında öğrencilere "Piyano dersini gerekli buluyor musunuz? Neden?", Size piyano dersini zorunlu veya seçmeli alma şansı verilseydi hangisini tercih ederdiniz? Neden?", Piyano dersine geldiğinizde kendinizi nasıl hissedersiniz? Neden?" "Piyano dersi için olumlu ya da olumsuz ne söylemek istersiniz?", "Piyano dersinden beklentiniz nedir, açıklayabilir misiniz?” soruları yöneltilmiştir.

\section{Verilerin Analizi}

Elde edilen nicel verilerin analizinde "aritmetik ortalama", "yüzde" ve "frekans" dağılımları kullanılmıştır. Öğrencilerin tutumları, cinsiyet ve piyano not ortalamaları göz önünde bulundurularak çift yönlü varyans analizi (ANOVA) ile test edilmiştir. Bunun yanında, öğrencilerin piyano not ortalamaları hesaplanıp; düşük, orta ve yüksek olmak üzere üç kategoriye ayrılmıştır. Görüşmelerden elde edilen nitel verilerin analizinde ise görüşmede yer verilen soruların cevapları doğrudan alıntılarla desteklenerek betimsel analiz yöntemi kullanılarak yorumlanmıştır (Yıldırım \& Şimşek, 2013).

\section{Bulgular ve Yorum}

$\mathrm{Bu}$ bölümde, araştırmanın sonuçlarına yönelik elde edilen bulgular tablolar halinde verilmiş ve yorumlanmıştır. 
Tablo 1.

Araştırmaya katılan öğrencilerin cinsiyet ve sınıf değişkenlerine göre dă̆llımı

\begin{tabular}{lllllll}
\hline & & Kadin & & Erkek & \multicolumn{2}{c}{ Toplam } \\
\hline Sinif & $n$ & $\%$ & $n$ & $\%$ & $n$ & $\%$ \\
1. Sinif & 7 & 18,5 & 3 & 7 & 10 & 25,5 \\
2. Sinıf & 7 & 18,5 & 2 & 6 & 9 & 24,5 \\
3. Sinif & 7 & 18,5 & 2 & 6 & 9 & 24,5 \\
4. Sinif & 7 & 18,5 & 3 & 7 & 10 & 25,5 \\
\hline Toplam & 28 & 74 & 10 & 26 & 38 & 100 \\
\hline
\end{tabular}

Tablo 1 incelendiğinde, çalışmada yer alan öğrencilerin \% 74'ünün kadın, \% 26'sının ise erkek öğrencilerden oluştuğu görülmektedir. Ayrıca araştırmada, 1. ve 4. sınıfta 10 kişi, 2. ve 3. sınıfta ise 9 kişi yer almıştır.

Tablo 2.

Araştırmaya katılan öğrencilerin yaş ve lise türü değişkenine göre dağılımı

\begin{tabular}{llllll}
\hline Lise Türü & $n$ & $\%$ & Yaş Değişkeni & $\mathrm{n}$ & $\%$ \\
\hline Düz Lise & 15 & 39,5 & $18-20$ yaş & 13 & 34,2 \\
Güzel Sanatlar Lisesi & 14 & 36,8 & $21-23$ yaş & 15 & 39,5 \\
Anadolu Lisesi & 9 & 23,7 & 24 ve üstü & 10 & 26,3 \\
\hline Toplam & 38 & 100 & Toplam & 38 & 100 \\
\hline
\end{tabular}

Tablo 2’de, çalışmaya katılan öğrencilerin \%39,5’i düz lise, \%36,8'i Güzel Sanatlar Lisesi ve \%23,7'si Anadolu lisesi mezunudur. Bununla birlikte, araştırmaya katılan öğrencilerin \% 34,2'si 18-20 yaş aralığında, \% 39,5'i 21-23 yaş aralığında, \% 26,3 'ü ise 24 yaş ve üstü yaş aralığındadır.

\section{Devlet Konservatuvarı Opera Anasanat Dalı öğrencilerinin piyano dersine ilişkin tutumlarına ait bulgular}

Aşağıda yer alan tabloda (Tablo 3.), Devlet Konservatuvarı Opera Anasanat Dalı öğrencilerinin piyano dersine ilişkin tutumlarını ölçmek için kullanılan ölçek ve öğrencilerin ölçekte yer alan maddelere verdikleri cevapların ortalaması ve standart sapma değerleri yer almaktadır.

Tablo 3.

Öğrencilerin piyano dersine ilişkin tutumlarını ölçmek amacıyla kullanılan anket maddelerinin ortalama ve standart sapma değerleri

\begin{tabular}{lcc}
\hline \multicolumn{1}{c}{ Maddeler } & $\bar{x}$ & S \\
\hline 1. "Piyano dersine hevesle gelirim." & 4.14 & 0.59 \\
2. "Piyano dersi ile ilişkili her şeye merak duyarım." & 3.84 & 0.73 \\
3. "En sevdiğim ders piyano dersidir." & 3.03 & 0.93 \\
4. "Piyano dersi hiçbir zaman ilgimi çekmedi." & 4.54 & 0.77 \\
5. "Piyano dersi olmaksızın tamamlanacak bir eğitimin yetersiz olacă̆ını & 4.43 & 0.90
\end{tabular}


düşünüyorum."

6. "Piyano ders saatlerinin artmasını isterim." $\quad 3.95 \quad 1.13$

7. "Beni müziğe bağlayan, piyano dersidir." $\quad 3.03 \quad 0.90$

$\begin{array}{llll}\text { 8. "Piyano dersini sabırsızlıkla beklerim." } & 3.32 & 0.91\end{array}$

$\begin{array}{lll}\text { 9. "Piyano dersi seçmeli bir ders olsa çok sevinirim." } & 2.97 & 1.30\end{array}$

$\begin{array}{lll}\text { 10. "Kendimi bildim bileli piyano dersi almak istemişimdir." } & 3.78 & 1.08\end{array}$

$\begin{array}{llll}\text { 11. "Bence piyano dersi müzik öğretmenleri için gereksizdir." } & 4.70 & 0.74\end{array}$

12. "Piyano dersini hiç kaçırmak istemem." $\quad 3.950 .94$

13. "Üniversiteyi bitirdikten sonra asla piyano dersi ile ilgili bir şey $\quad 4.59 \quad 0.83$

görmek istemiyorum."

$\begin{array}{ll}4.59 & 0.83 \\ 3.68 & 1.06\end{array}$

14. "Piyano derslerine katılamadığımda üzülürüm." $\quad 3.68 \quad 1.06$

$\begin{array}{llll}\text { 15. "Piyano dersinde huzur bulurum." } & 3.68 & 0.71\end{array}$

16. "Piyano dersinden keyif almiyorum." $\quad 3.84 \quad 1.34$

17. "Keşke her ders piyano dersi gibi olsa." $\quad 3.43 \quad 0.96$

18. "Piyano derslerinde verilen her eseri ayırt etmeksizin zevkle çalışırım." $3.41 \quad 1.04$

19. "Piyano derslerinin neden zorunlu olduğunu anlayamıyorum." $\quad 3.89 \quad 1.15$

20. "Piyano dersi benim için her zaman önemli olmuştur." $\quad 4.05 \quad 1.00$

21. "Piyano dersinden sonra kendimi bıkkın hissederim." $\quad 3.70 \quad 1.02$

22. "Piyano dersine geç kalmak bile beni çok rahatsı eder." $\quad 3.73 \quad 0.96$

23. "Piyano dersiyle ilgili etkinliklere severek katılırım." $\quad 3.95 \quad 0.94$

24. "Piyano dersinin önümde bir engel gibi olduğunu hissederim." $\quad 4.38 \quad 0.95$

25. "Piyano dersinde verilen ödevleri severek yaparım." $\quad 3.70 \quad 0.70$

26. "Piyano dersinin beklentilerime cevap vermediğini düşünürüm." $\quad 3.78 \quad 1.00$

27. "Piyano ve piyano dersiyle ilgili konuşmaktan büyük zevk alırım." $\quad 3.70 \quad 0.94$

28. "Piyano dersinin saatleri keşke daha fazla olsa." $\quad 3.84 \quad 1.12$

29. "Piyano dersinin benim yeteneğimi ortaya çıkaramadığını düşünürüm.” $4.11 \quad 0.88$

30. "Piyano dersi sıkıcı bir derstir." $\quad 4.51 \quad 0.87$

Genel olarak bakıldığında, piyano dersine ilişkin tutumları ölçmek için kullanılan ankette yer alan maddelerin ortalaması 3.87'dir. Bu durumda Devlet Konservatuvarı Opera Anasanat Dalı öğrencilerinin "Piyano Dersine Yönelik Tutum Ölçeğinin” anket maddelerine çoğunlukla katılmış oldukları görülmektedir. Alt boyutların ortalamaları göz önünde bulundurulduğunda "hoşnutluk" alt boyut ortalaması 3.68 "değer" alt boyut ortalaması ise 4.12 ' dir.

Genel olarak ortalamalara bakıldığında Tablo 3,1'de görüldüğü gibi, öğrencilerin anket sorularına verdiği cevapların içinde en yüksek ortalamanın 4.70 ile "Bence piyano dersi müzik öğretmenleri için gereksizdir" maddesine ait olduğu görülmektedir. Ortalaması yüksek diğer bir madde ise 4.59 ile "Üniversiteyi bitirdikten sonra asla piyano dersi ile ilgili bir şey görmek istemiyorum" maddesidir.

En düşük ortalamanın ise 2.97 ortalama ile "Piyano dersi seçmeli bir ders olsa çok sevinirim." maddesine ait olduğu saptanmıştır. "En sevdiğim ders piyano dersidir" ve 
"Beni müziğe bağlayan, piyano dersidir" maddeleri de 3.03 ile ortalaması en düşük diğer maddeler olarak görülmektedir.

Aşağıdaki tabloda (Tablo. 4) ise, Devlet Konservatuvarı Opera Anasanat Dalı öğrencilerinin piyano dersine ilişkin tutumları arasında cinsiyet ve piyano not ortalamaları değişkenleri açısından anlamlı bir farklılık olup olmadığını saptamak için yapılan çift yönlü varyans analizi sonuçları verilmiştir.

Devlet Konservatuvarı Opera Anasanat Dalı öğrencilerinin piyano dersine ilişkin tutumlarının cinsiyet değişkeni ve piyano dersi not ortalamalarına göre farklılık gösterip göstermediğine ilişkin bulgular

Tablo 4.

Katılımciların cinsiyet ve piyano not ortalama puanlarına ilişkin varyans analizi sonuçlart

\begin{tabular}{|c|c|c|c|c|c|}
\hline $\begin{array}{l}\text { Çift Yönlü Varyans } \\
\text { Analizi Sonuçları }\end{array}$ & $\begin{array}{l}\text { Serbestlik } \\
\text { Derecesi }\end{array}$ & $\begin{array}{l}\text { Kareler } \\
\text { Ortalamas1 }\end{array}$ & F İstatistiği & Anlamlılik & Eta-kare \\
\hline Cinsiyet & 1 & 2.757 & 10.540 & 0.063 & 0.025 \\
\hline Piyano Not Ort. & 2 & 1.913 & 7.326 & 0.002 & 0.314 \\
\hline Cinsiyet* Piyano Ort. & 2 & 0.982 & 3.759 & 0.541 & 0.015 \\
\hline Hata & 32 & 0.261 & - & - & - \\
\hline
\end{tabular}
$* p<.05$

Tablo 4. incelendiğinde, çift yönlü varyans analizi sonuçlarına göre öğrencilerin piyano dersine ilişkin tutumları arasında cinsiyet değişkenine göre anlamlı bir fark olmadığ görülmektedir $(\mathrm{p}=0.063>0.05)$. Piyano not ortalamalarına bakıldığında ise, anlamlı bir farklılaşma olduğu sonucu elde edilmiştir $(\mathrm{p}=0.002<0.05)$. Araştırma sonucunda ortaya çıkan bu farklılaşmanın, hangi kategoriler arasında olup olmadığını anlamak amacıyla Tukey HSD testi yapılmıştır.

Tablo 5 .

Katılımcıların piyano not ortalama puanlarına ilişkin ortalama ve standart sapma sonuçları

\begin{tabular}{cccc}
\hline & Ortalama & Standart Sapma & $\mathrm{N}$ \\
\hline Zaylf & 3,6972 &, 78553 & 12 \\
Orta & 3,8157 &, 50694 & 9 \\
İyi & 4,0314 &, 45238 & 17 \\
Total & 3,8748 &, 59148 & 38 \\
\hline
\end{tabular}

Tukey HSD testinin sonuçları incelendiğinde, piyano not ortalaması zayıf düzeyde olan öğrencilerin tutumları $(\bar{x}=3.70, \mathrm{~S}=0.79)$, piyano not ortalaması iyi düzeyde olan öğrencilerin tutumlarından $(\bar{x}=4.03, S=0.45)$ anlamlı düzeyde $(\mathrm{p}<0.05)$ daha düşüktür olduğu görülmektedir (Tablo 5.) 


\section{Devlet Konservatuvarı Opera Anasanat Dalı öğrencilerinin piyano dersine yönelik tutumlarına ilişsin görüşme bulguları}

Öğrencilerin piyano dersine yönelik tutumlarının ne düzeyde olduğunu belirlemek amacıyla öğrencilerle yarı-yapılandırılmış mülakat yapılmıştır. Öğrencilerin görüşmede yer alan "Piyano dersini gerekli buluyor musunuz?" sorusuna verdikleri cevaplar incelendiğinde, öğrencilerin tamamının $(\mathrm{f}=7)$ piyano dersinin gerekli olduğuna inandıkları ortaya çıkmıştır. Bununla ilgili bir öğrenci; "Konservatuvar öğrencisi olarak; şan eserlerimi ve diğer eserlerimi çalışmamda bana yardımcı oluyor. Ayrıca sesleri doğru bir şekilde vermemde de büyük katkısını görüyorum. "ifadelerini kullanmıştır. Diğer öğrenciler de bu ifadelere paralel cevaplar vermiştir. Buna ek olarak öğrencilerden ikisi $(\mathrm{f}=2)$ piyanonun huzur verici ve stresi azaltan bir çalg1 olduğunu belirtmiştir. Bunun yanında bazı öğrenciler $(\mathrm{f}=3)$ ise piyano dersinin müzik kulağı gelişimine katkısı olduğunu ifade etmişlerdir.

Öğrencilerin görüşmede yer alan "Size piyano dersini zorunlu veya seçmeli alma şans1 verilseydi hangisini tercih ederdiniz?" sorusuna verdikleri cevaplar incelendiğinde öğrencilerin tamamının $(\mathrm{f}=7)$ piyano dersinin zorunlu olması gerektiğini düşündükleri görülmüştür. Fakat bir öğrenci ( $\mathrm{f}=1)$ sonraki yıllarda ders yoğunluğunun artması sebebiyle piyano dersinin sadece ilk iki yıl zorunlu olması gerektiğini belirtmiş̧ir. Ayrıca öğrencilerden bir tanesi ( $\mathrm{f}=1$ ) "iyi bir müzisyen olmanın koşulu piyanoyla iç içe olmaktan geçiyor. Piyano, bir müzisyenin yaşamında her daim yer almalıdır" ifadelerine yer vermiştir.

Öğrencilerin görüsşmede yer alan "Piyano dersine geldiğinizde kendinizi nasıl hissedersiniz?" sorusuna verdikleri cevaplar incelendiğinde bazı öğrencilerin ( $f=2)$ piyano dersinde kendilerini tedirgin, gergin ve heyecanlı hissettiklerini ifade ettikleri görülmüş̧ür. Öğrenciler bunun sebebi olarak ise dersi veren öğretim elemanının dersteki negatif tavırlarının etkili olduğunu belirtmiştir. Bir başka öğrenci ise ( $\mathrm{f}=1)$ piyano dersinde kendisini sevinçli ve aynı zamanda gergin hissettiğini dile getirmiş̧ir. Her ne kadar öğrencinin piyanoyu sevme ve çalma isteği ağır bassa da bunun o kadar kolay olmadığının bilinmesinin verdiği endişe, öğrencinin farklı duygu durumu içerisinde olmasına sebebiyet vermiştir. Diğer bir öğrenci $(\mathrm{f}=1)$ "Genellikle çalamadığımı düşündüğüm için gergin hissediyorum. Çünkü çalgı çalmaktan keyif almıyorum" ifadelerine yer verirken, başka bir öğrenci de (f=1) "Eğer çalıştıysam sevinçli ve huzurlu hissederim çünkü özgüvenim yerindedir. Fakat çalışmadıysam tedirgin ve gergin olurum, çünkü çalışmamanın verdiği suçluluk psikolojisi beni etkiler" ifadesinde bulunmuştur.

Öğrencilerin görüşmede yer alan "Piyano dersi için olumlu ya da olumsuz ne söylemek istersiniz?" sorusuna verdikleri cevaplar incelendiğinde öğrencilerin çoğu $(\mathrm{f}=5)$ piyano dersiyle ilgili olumlu ifadelere yer vermiştir. Söz konusu öğrencilerin piyano dersine iliş̧in düşüncelere şu şekilde olmuştur: Bir çalgıyı tanımak ve çalgının dilini çözmek muazzam bir duygu. Piyano dersi, zihinlerde mutlu ve umutlu hisler uyandırmasının yanında, zeka ve müzikalite gelişimine sağladığını katkı ile de güzel 
ve kaliteli zaman geçirmesine imkan veriyor. Bazı öğrenciler ise ( $\mathrm{f}=2)$ piyano dersi için hem olumlu hem olumsuz ifadeler kullanmışlardır. Bu öğrenciler olumlu ifade olarak, müzikle ilgili diğer faaliyetlerde faydasını gördüklerini ve piyano müziği dinleme alışkanlıklarının arttığını söylerken, olumsuz ifade olarak ise el ve kol ağrıları gibi fiziksel sıkıntı yaşadıklarını, piyano çalmakta zorlandıkları için gergin olduklarını belirtmişlerdir.

Öğrencilerin görüşmede yer alan "Piyano dersinden beklentiniz nedir?” sorusuna verdikleri cevaplar incelendiğinde, çoğu öğrenci $(\mathrm{f}=5)$ şan egzersizlerini ve şan eserlerinin eşliklerini piyanoda yeterli düzeyde çalabilmek istediklerini ifade etmiştir.

\section{Tartışma, Sonuç ve Öneriler}

Bu çalışmada, Devlet Konservatuvarı Opera Anasanat Dalı öğrencilerinin piyano dersine ilişkin tutumlarının incelenmesi amaçlanmıştır. Bu çalışma, bu yönüyle daha önce yapılan araştırmalardan farklılık göstermektedir. Daha önceki araştırmalar incelendiğinde, çalışmaların genellikle müzik eğitimi bölümü ile güzel sanatlar lisesi öğrencilerinin piyano dersine ilişkin tutumları üzerine yoğunluk kazandığ görülmektedir (Bakığlu \& Kurtuldu, 2015; Çevik \& Güven, 2011; Demirtaş \& Onuray Eğilmez, 2015; Gün \& Köse, 2013; Halvaşi, 2019; Kılınçer \& Karkın, 2011; Soycan \& Hamzaoğlu Birer, 2018; Tufan \& Güdek, 2008; Ünal, 2017; Yaz1c1, 2019).

Araştırmanın birinci alt probleminin yanıtlanması amacıyla yapılan analiz sonuçları, öğrencilerin piyano dersine yönelik tutumları ile cinsiyet değişkeni arasında anlamlı bir farklılığın olmadığını göstermiştir. Araştırmada yer alan öğrencilerin genel ağırlığının kadın olmasının, bu sonucun ortaya çıkmasını sağlamış olabileceği düşünülmektedir. Opera Anasanat Dalları genel olarak incelendiğinde, gerek yetenek sınavına başvuran gerekse de eğitim gören öğrencilerin genel ağırlığının kadın olduğu görülmektedir. Ünal'ın (2017) yaptığı çalışmada ise müzik öğretmeni adaylarının piyano dersine ilişkin tutumları ile cinsiyet değişkeni arasında, kadın müzik öğretmeni adaylarının erkek müzik öğretmeni adaylarında göre olumlu bir tutum sergilediği belirtilmektedir.

$\mathrm{Bu}$ çalışma ile paralellik gösteren çalışma, cinsiyet değişkenleri açısından kadın öğrencilerin erkek öğrencilere göre daha olumlu bir tutum sergilediği sonucu ile ise farklılaşmaktadır. Farklılığın nedeni olarak, bu çalışmada öğrencilerin cinsiyet değişkeni ile tutum arasında anlamlı bir farklılık olmazken, Ünal (2017) tarafindan yapılan çalışmada kadın öğrencilerin daha yüksek tutum gösterdiği sonucu elde edilmiştir.

Araştırmanın ikinci alt probleminin yanıtlanması amacıyla yapılan analiz sonuçları, öğrencilerin piyano dersine yönelik tutumları ile piyano dersi not ortalamaları arasında anlamlı bir farklılık olduğunu göstermişstir. Bunun anlamı, araştırmaya katılan öğrencilerin piyano dersine ilişkin sınav notları ile derse yönelik tutumları arasında bir paralellik olduğudur. Daha açık bir ifadeyle, opera anasanat dalı 
öğrencilerinden piyano dersine ilgisi düşük olan öğrenciler ile yüksek olan öğrenciler arasında, tutum ve not ortalaması açısından da benzerliklerin olduğu söylenebilir. $\mathrm{Bu}$ anlamlı farklılığın nedenleri arasında, birçok faktör etkili olabilmektedir. Bunlardan bazıları; öğrencilerin ilgi durumlarının farklılığı, eğitimci faktörü, pedagojik yaklaşım, doğru ya da yanlış repertuvar ile eğitimci ve öğrenci arasındaki iletişim gibi etkenlerdir. Bu faktörler öğrencilerin piyano dersine karşı tutumları üzerinde etkili olabilmektedir. Bu durumun olabilme olasılığını azaltmak adına, öğrencilerin not ortalamaları ile derse yönelik tutumlarını karşılaştırma yoluna gidilmiş̧ir. Sonuç olarak, öğrencilerin derse yönelik tutumları ile not ortalamalarının da benzer yönde olduğu sonucu elde edilmiştir. Derse olan tutumu zayıf olan öğrencinin, not ortalaması da aynı şekilde, aşağı yöne doğru bir izlenim sergilemiştir.

Ayrıca piyano not ortalamaları düşük düzey - orta düzey arasında olan öğrencilerin tutumları ile not ortalamaları orta düzey - yüksek düzey arasında olan öğrencilerin tutumları arasında anlamlı bir farklılık olmadığı, bunun yanında düşük düzey - yüksek düzey arasında olan öğrencilerin tutumları arasında anlamlı bir farklılık olduğu sonucu elde edilmiştir.

Araştırmanın üçüncü alt probleminin yanıtlanması amacıyla yapılan analiz sonuçlarına göre, Devlet Konservatuvarı Opera Anasanat Dalı öğrencilerinin piyano dersine ilişkin tutumlarını ölçmek amacıyla kullanılan ankette yer alan maddelerin ortalaması 3.87'dir. Buna göre Devlet Konservatuvarı Opera Anasanat Dalı öğrencilerinin "Piyano Dersine Yönelik Tutum Ölçeğinin" anket maddelerine çoğunlukla katılmış oldukları görülmektedir. Çevik ve Güven (2011) müzik öğretmeni adaylarının piyano dersine ilişkin tutumlarını değerlendirmek amacıyla yaptıkları çalışmada ise, öğretmen adaylarının piyano dersine yönelik tutumlarının zayıf düzey olduğunu ortaya koymuştur. Bu çalışmada da aynı şekilde Tufan ve Güdek (2008) tarafindan geliştirilen "Piyano Dersine Yönelik Tutum Ölçeği" kullanılmıştır. Sönmezöz'ün (2014) müzik öğretmeni adaylarıyla yaptığı çalışma ise, adayların piyano dersine yönelik tutumlarında olumlu yönde bir sonuç ortaya koyduğunu belirtmiştir. Bu doğrultuda Sönmezöz'ün (2014) yaptığı çalışma sonucu ile bu araştırmanın sonucu arasında bir benzerlik olduğu görülmektedir. Karabulut (2009) ise yaptığı çalışmada katılımcıların piyano dersine ilişkin tutumlarının karasızlık yönünde olduğunu belirtilmektedir. Diğer bir çalışma ise, Ünal (2017) tarafindan gerçekleştirilmiş olup, araştırmada müzik öğretmeni adaylarının piyano dersine ilişkin tutumlarının pozitif yönde olduğu sonucuna ulaşılmıştır.

Öğrencilerin piyano dersine yönelik tutumlarının ne düzeyde olduğunu belirlemek amacıyla öğrencilerle yapılan görüşmeler sonucunda; öğrencilerin genel olarak piyano dersinin gerekli olduğuna inandıkları ve piyano dersinin zorunlu olması gerektiğini düşündükleri ortaya çıkmıştır. Bununla birlikte, bazı öğrenciler piyano dersinde gerek öğretim elemanlarının olumsuz yaklaşımından, gerek kendilerini yetersiz hissetmelerinden dolayı tedirgin, gergin ve heyecanlı hissettiklerini ifade etmişlerdir. Bunlara ek olarak, bazı öğrenciler ise; piyano dersinde yaşadıkları 
güçlüklerle rağmen bu dersin kendilerinde iyi hisler uyandırdığını belirtmişlerdir. Ayrıca, öğrencilerin çoğunun, kendi çalıştıları eserlerin eşliklerini piyanoda çalabilecek düzeyde eğitim alabilmeyi istedikleri ortaya çıkmıştır.

$\mathrm{Bu}$ bulgular 1şığında; araştırmanın kapsamı ve örneklemi geliştirildiği takdirde, daha net sonuçlara ulaşılabilecektir. Öğrencilerin piyano dersine ilişkin tutumlarını geliştirmek için farklı yöntemler geliştirilmeli, literatürden örnekler aracıllğıyla gelişimin olumlu yönde olmasına katkı sağlanma yolu tercih edilmelidir. Teknik sorun yaşanabilecek durumlarda ise, eğitimcinin farklı materyaller kullanmaya açık olması ve eser seçiminin kolaydan zor eserlere doğru seçilmesi, öğrencilerin piyano dersine ilişkin tutumları üzerinde olumlu etki oluşmasını sağlayacaktır.

\section{Etik Bildirimi}

Yazarlar arasında çıkar çatışması bulunmadığını ve tüm araştırmacıların çalışmaya eşit oranda katkı sunduğunu beyan etmiş̧tir. Yazarlar tüm etik kurallara uyduklarını bildirmiştir.

\section{Kaynakça}

Bakığlu, Ç., \& Kurtuldu, M. K. (2015). Piyano dersine yönelik tutum ölçeği geliştirme çalı̧̧ması. Alan Eğitimi Araştırmaları Dergisi (ALEG), 1(1), 33-39.

Baydağ, C. (2020). Üniversitelerin farklı lisans bölümlerinde öğrenim gören öğrencilerin müziğe yönelik ilgi düzeylerinin incelenmesi. Firat Üniversitesi Sosyal Bilimler Dergisi, $30(1), 1-17$.

Bloom, B. S. (1995). İnsan nitelikleri ve okulda öğrenme (çev. D. A. Özçelik). MEB Yayınları.

Canakay, U, E. (2006). Müzik teorisi dersine ilişkin tutum ölçeği geliştirme. Ulusal Müzik Eğitimi Sempozyumu Bildirisi, Pamukkale Üniversitesi Eğitim Fakültesi, Denizli: 26-28 Nisan.

Creswell, J. W. \& Plano Clark, V. L. (2015). Karma yöntem araştırmaları: Tasarımı ve yürütülmesi. An1 Yayınları.

Çelik Nayır, Y. (2018). Güzel sanatlar liselerinde piyano eğitiminin teknik ve pedagojik açıdan incelenmesi (Tez No. 495724) [Yüksek Lisans Tezi, Haliç Üniversitesi-İstanbul]. Yükseköğretim Kurulu Başkanlığı Tez Merkezi.

Çevik, D. B., \& Güven, E. (2011). Müzik öğretmeni adaylarının piyano dersine yönelik tutumlarının değerlendirilmesi. Buca Eğitim Fakültesi Dergisi, 29, 103-120.

Çöllü, E. F., \& Öztürk, Y. E. (2006). Örgütlerde inançlar - tutumlar tutumların ölçüm yöntemleri ve uygulama örnekleri bu yöntemlerin değerlendirilmesi. Selçuk Üniversitesi Sosyal Bilimler Meslek Yüksek Okulu Dergisi, 9(1-2), 373-404.

Demirtaş, S., \& Onuray Eğilmez, H. (2015). Müzik Eğitimi Anabilim Dalı 4. sınıf öğrencilerinin piyano dersine karşı tutumlarının eşlik dersi başarı durumları ile karşılaştııılması. Jasss Internatıonal Journal of Social Science, 31, 421-428. 
Ekici, T. (2012), Bireysel ses eğitimi dersine yönelik tutum ölçeğinin geliştirilmesi. Gazi Üniversitesi Gazi Ĕgitim Fakültesi Dergisi, 32(3), 557-569.

Eren, E. (2001). Örgütsel davranış ve yönetim psikolojisi. Beta Basım Yayım ve Dağıtım.

Gasımova, T. (2010). Piyano öğrenme ve öğretme teknikleri. Atatürk Üniversitesi Güzel Sanatlar Enstitüsü Dergisi, 25, 99-106.

Göncü, İ. Ö. (2016). 4-6 Yaş anaokulu çocuklarına uygulanan müzik eğitiminin müziksel ses ve işitsel alg1 gelişimlerine etkileri. Abant İzzet Baysal Üniversitesi Eğitim Fakültesi Dergisi, 16, 2382-2392.

Gün E., \& Köse H. S. (2013). Müzik öğrencilerinin piyano dersine yönelik tutumları. Turkish Studies-International Periodical For The Languages, Literature and History of Turkish or Turkic 8(3), 247-261.

Gürşen Otacıŏlu, S. (2010). Müzik öğretmeni adaylarının okul deneyimi II uygulama dersine ilişkin tutumları. Pamukkale Üniversitesi Ĕ̈itim Fakültesi Dergisi, 28(2), 81-90.

Halvaşi, B. (2019). Attitudes of pre-service music teachers studying in undergraduate programs in turkey towards piano courses. Journal of Education and Training Studies. 7(2), 142-147.

İnceoğlu, M. (2004). Tutum, Algl, İletişim. Elips Yayınevi.

Kağıtçıbaşı, Ç. (2005). Yeni insan ve insanlar: sosyal psikolojiye giriş. Evrim Yayınevi.

Karabulut, G. (2009). Eğitim fakültesi müzik eğitimi anabilim dalı 1.ve 3.sınıf öğencilerinin piyano dersine yönelik tutumlarının incelenmesi (Tez No. 234380) [Yüksek Lisans Tezi, Gazi Üniversitesi-Ankara]. Yükseköğretim Kurulu Başkanlığı Tez Merkezi.

Kılıç, I. (2006). AGSL Öğrencilerinin Piyano Derslerindeki Başarı Durumlarının Değerlendirilmesi. Ulusal Müzik Eğitimi Sempozyumu Bildirisi, Pamukkale Üniversitesi Eğitim Fakültesi, Denizli: 26-28 Nisan.

Kılınçer Ö., \& Karkın, A. M. (2011). Güzel sanatlar ve spor liseleri müzik bölümlerinde piyano dersine yönelik tutumlar üzerine bir araştırma. Fine Arts, e-journal of New World Sciences Academy, 6(3), 356-366.

Özen, M. (1998). Gazi Üniversitesi Gazi Eğitim Fakültesi Müzik Eğitimi Bölümü son sınıf öğrencilerinin piyanoyu müzik öğretmenliğinin gerekleri doğrultusunda kullanma becerileri (Tez No. 76414). [Doktora Tezi, Gazi Üniversitesi-Ankara]. Yükseköğretim Kurulu Başkanlığı Tez Merkezi.

Öztürk, Ö., \& Kalyoncu, N. (2018). İlköğretim altıncı sınıf müzik dersinde kullanılan tam öğrenme modelinin öğrencilerin tutum ve başarılarına etkisi. Türk Ĕ̈itim Bilimleri Dergisi. $16(1), 1-25$.

Pallant, J. (2007). SPSS survival manual. Open University Press.

Soycan, M., \& Hamzaoğlu Birer, A.R. (2018). Piyano dersine yönelik tutum ölçeği geliştirme çalışması. Turkish Studies-Educational Sciences, 13(11), 1237-1248.

Sönmezöz, F. (2014). Müzik öğretmeni adaylarının piyano dersine ilişkin tutumlarının belirlenmesi. Turkish Studies- International Periodical For The Languages, Literature and History of Turkish or Turkic, 9(2), 1377-1388. 
Şendurur, Y., \& Akgül Barış, D. (2002). Müzik eğitimi ve çocuklarda bilişsel başarı. Gazi Üniversitesi Ĕ̈itim Fakültesi Dergisi, 22(1), 165-174.

Tufan, E., \& Güdek, B. (2008). Piyano dersi tutum ölçeğinin geliştirilmesi. Gazi Üniversitesi Gazi Eğitim Fakültesi Dergisi, 28(1), 75-90.

Türkmen, E., F. (2018). Pedagojik formasyon eğitimi alan konservatuvar öğrencilerinin öğretmenlik uygulaması dersine yönelik yeterliklerinin değerlendirilmesi. Turkish StudiesEducational Sciences, 13(11), 1347-1366.

Uçan, A. (1994). Müzik eğitimi, temel kavramlar ilkeler yaklaşımlar. Müzik Ansiklopedisi Yayınları.

Ünal, B. (2017). Müzik öğretmeni adaylarının piyano dersine yönelik tutumlarının değerlendirilmesi. Online Journal of Music Sciences, 2( 3), 163-178.

Yazıcı, T. (2013). "Piyano Öğretiminde Karşılaşılan Sorunların Piyano Öğretmenleri Tarafından Değerlendirilmesi”, SED-Sanat Eğitimi Dergisi. 1(2), 130-150.

Yazıcı, T. (2019). Güzel sanatlar lisesi müzik bölümü öğrencilerinin piyano dersine ilişkin tutumlarının metaforik analizi. Turkish Studies, 14(3), 1917-1926.

Yıldırım, A., \& Şimşek, H. (2013). Nitel Araştırma Yöntemleri. (9.Baskı), Seçkin Yayınları.

\section{Extended Abstract}

Considering music education in general and piano education in particular, it is seen that many factors affect the education process positively or negatively. In this sense, one of the factors that affect students' academic success and career status is undoubtedly the attitude. Attitude is a tendency that regularly creates individuals' thoughts, feelings and behaviors about the psychological object (Kağıtçıbaşı, 2005). Attitudes are found in the mind of the individual and form a basis for many thoughts and behaviors (Gürşen Otacioğlu, 2010), and there is an important relationship between attitudes and student success (Ekici, 2012). From this point of view, research is important in terms of determining the attitudes of the State Conservatory opera department students regarding the piano lesson, both having knowledge about the success of the piano education program related to student development, as well as determining and solving problem situations on attitudes as a result of the applied scale. The aim of this study was to investigate the attitudes of the State Conservatory Opera Department students towards the piano lesson. In addition, in the study, it was tried to determine whether there is any difference in terms of students' attitudes and their gender and piano grade averages.

Survey model, which is one of the quantitative research methods, was used in the research. Quantitative data were supported by qualitative data to analyze students' attitudes towards piano lessons in depth. The sample of the study consisted of 38 conservatory students studying at a public university in the Western Black Sea region in the spring semester of the 2016 - 2017 academic year. The study group of the study 
consisted of 38 students, $28(74 \%)$ women and $10(26 \%)$ men, who received undergraduate education in the spring semester of 2016-2017 academic year at State Conservatory Performing Arts Department Opera Department of a university in the Western Black Sea region was formed. The "Attitude Scale for Piano Lesson" developed by Tufan and Güdek (2008) was used to determine the level of attitudes of Opera department students about the piano lesson. Cronbach Alpha reliability coefficient of the scale was calculated as 0.94. According to this result, it can be said that the scale is a reliable scale to measure students' attitudes towards the piano lesson (Pallant, 2007). The scale includes a total of 30 question items to measure students' attitudes towards the piano lesson. Negative rooted items were scored by inverting. In addition, demographic data such as piano grade averages and gender variable were collected in the study. Semi-structured interviews were conducted with seven randomly selected students to collect the qualitative data of the study. During the interview, five questions were asked to the students to investigate their attitude towards the piano lesson. Two-way analysis of variance and "arithmetic mean", "percentage" and "frequency" distributions were used to analyze quantitative data. In addition, students' piano grade averages are calculated; it is divided into three categories: weak, medium and good. In the analysis of qualitative data, descriptive analysis method was used.

In general, the average of the items in the questionnaire used to measure attitudes towards the piano lesson is 3.87. In this case, it is seen that the students of the opera department of the state conservatory have mostly participated in the questionnaire of the "Attitude Scale towards the Piano Lesson". It is seen that among the responses given by the participants to the questionnaire items, the highest average is 4.70 and it is reversed and scored by being reversed and it belongs to the item "I think piano lesson is unnecessary for music teachers". The lowest average was found to be "I would be very happy if the piano lesson is an elective course" with an average of 2.97. According to the results of Two Way ANOVA Test conducted to investigate whether there is a significant difference between the attitudes of the State Conservatory Opera Department students in terms of gender and piano grade averages, there was no significant difference between the students' attitudes towards the piano lesson according to the gender variable $(\mathrm{p}=0.063>0.05)$. When the piano grade averages are analyzed, it is concluded that there is a significant difference $(\mathrm{p}=0.002<0.05)$. Tukey HSD test was carried out in order to understand between which categories the significance difference was. According to the results of the Tukey HSD test in Table 5 , the attitudes of students with poor piano scores $(\bar{x}=3.70, \mathrm{~S}=0.79)$, were compared to the attitudes of students with good piano scores $(\bar{x}=4.03, \mathrm{~S}=0.45)$ was found to be significantly lower.

As a result of the research, there was no significant difference the attitudes of the students studying in the State Conservatory Opera Department, compared to the gender variable, while there was a significant difference between the average scores 
of the piano lesson and the attitudes. It was concluded that the students' attitudes towards the piano lesson were moderate. 